\title{
Cyanobacterium Petalonema alatum BERK. ex KIRCHN. - species variability and diversity
}

\author{
Bohuslav UHER \\ Department of Botany and Zoology, Masaryk University, Kotlářská 2, CZ-611 37 Brno, Czech Republic; e-mail: \\ uherius@sci.muni.cz
}

\begin{abstract}
Petalonema alatum is an interesting cyanobacterial species of subaerial calcareous habitats in gorges of the National Park Slovenský raj, Slovakia. Observation of different morphological forms in natural and culture materials is demonstrated and discussed. Cultures of $P$. alatum differed from natural populations mainly in the width of the filament apex, massiveness of mucilage sheaths, and degree of heteropolarity. This means that these features are more likely controlled by environmental variables. Other characteristics (heteropolarity, false branching, sheath structure) were found to be stable and consequently can have taxonomical importance.
\end{abstract}

Key words: cyanobacterium, Petalonema alatum, Microchaetaceae, subaerial habitat, morphometric analysis, National Park Slovenský raj, Slovakia

\section{Introduction}

Petalonema alatum was described as Oscillatoria alata for the first time and also illustrated later by Carmichael (in Greville 1823, fig. 1-60; 1826, fig. 181-240) from wet rocks from Scotland (Argyll, Appin) as "stratum rufo-fuscum, filis brunneis, minutis, late alatis, alis albidis." However, Berkeley (1833, p. 23, tab.7, fig. 2) synonymized it to a new established name Petalonema alatum and Borzi (1879) combined it with Scytonema densum (A.Braun) Bornet under a new name Scytonema alatum. Itzigsohn (1855, p. 165) even combined Petalonema alatum with Scytonema myochrous. Although this species has long been known (Tables 1 and 2), its taxonomy has still not been clarified and the range of its morphological variability under different conditions is unknown. The present study focuses on morphological variation of natural population of Petalonema alatum in comparison to clones growing under laboratory conditions and to published data (Tables 1 and 2).

\section{Material and methods}

Samples were taken from a wet calcareous wall of the Piecky Gorge (Vel'ký vodopád waterfall) in the National
Park Slovenský raj (Slovakia). The substrate hosting an algal biofilm was limestone ( $90 \%$ of calcite, and $4 \%$ of quartz, from Powder Diffraction data). The samples were collected by random scraping of rock surface (2-4 $\mathrm{mm}$ ) into sterile tubes during summer seasons (June $24^{\text {th }} 1998$, August $1^{\text {st }} 1999$, September $27^{\text {th }} 2000$, July $9^{\text {th }} 2002$, August $7^{\text {th }} 2005$ and on September $16^{\text {th }}$ 2007). Environmental variables (relative humidity and temperature) were measured ( 1 meter above the soil surface) using a thermo-hygrometer (Mütec Instruments $\mathrm{GmbH}$, Germany). Irradiance values were measured using a radiometer equipped with a quantum sensor (Excellent Technology Co., Italy). Both natural samples and isolates maintained in cultures were observed and documented using an Olympus BX 50 light microscope equipped with Lucia Image Analysis and stereomicroscope Olympus SZH. Cultures were kept in Petri dishes and tubes containing culture medium BBM (SмIтн \& BoLD, 1966) under controlled conditions (temperature $21^{\circ} \mathrm{C}$, humidity $60 \%$, irradiance $10.3 \mu \mathrm{mol} . \mathrm{s}^{-1} \cdot \mathrm{m}^{-2}$, light $660 \mathrm{~lx}$, (PhAR) $2.14 \mathrm{~W} \cdot \mathrm{m}^{-2}$ and in a photoperiod 12:12h light:dark). The initial sample incubation in Petri dishes (7-21 days) was followed by isolation of clones. The following morphometric data were measured from natural populations (60 specimens) and from cultures (60 specimens): Apical zones - width of filament apex; heterocyte zones width of the part with the first heterocyte; terminal zones - width of terminal part (with many heterocytes). Afterwards these data were statistically visualised using the program STATISTICA $\left(\right.$ StatSoft $\left.^{\circledR}\right)$. Dimensions of cells, trichomes, and filaments of cyanobacteria 
from the wild sample and the cultivation sample were compared using the Wilcoxon Signed Ranks Test (C) Microsoft Excel).

\section{Results}

\section{Morphology and taxonomy}

Natural samples were dominated by $P$. alatum. The dominant cyanobacterium was accompanied by other coccal and trichal cyanobacteria. Crusts with Petalonema were caespitose, mucilaginous, from yellowish green or greyish green to blackish brown in colour. Petalonema alatum is classified as an euendolithic species, which actively penetrates the calcareous substrate. The major part of filaments was inside the limestone rock, except for the wide apical parts. Filaments of $P$. alatum were flexuous, loosely entangled, single or branching, procumbent, and about $2500 \mu \mathrm{m}$ long, (25)30-115(130) $\mu \mathrm{m}$ broad; heteropolarity was obvious. False branching was observed at heterocytes (Figs 1d, e); sheaths were very thick, with distinct funnel-shaped mucilage sheaths consisting of divergent layers (Fig. 1b). Inner layers were from yellowish, yellow, orange to brown (in old filaments), outer layers were colourless or yellowish (in old filaments). Trichomes were typically constricted at the cross walls, heteropolar, with apical meristematic zones, with rounded or globular apical cells (Figs 1b-d, $\mathrm{f} ; 2 \mathrm{a}, \mathrm{b}, \mathrm{k}-\mathrm{n}$ ). Cells at the apical growing region were short and barrel shaped, in older parts long and cylindrical, up to twice as long as broad (5)6$15(18) \times(4) 5-8(9) \mu \mathrm{m}$. Heterocytes were basal or intercalary, (12.5)15-17.5 × (5)7.5-10.5 $\mu \mathrm{m}$. Hormogonia occurred rarely in the apical part of the filaments (Figs 2d, n).

Cultures of $P$. alatum were not axenic. Mucilaginous cyanobacteria are usually accompanied by microorganisms such as bacteria, fungi, small coccal green algae or cyanobacteria, and diatoms. Petalonema grown on an agar plate forms mucilaginous, compact, dark-green colonies; filaments were horizontal or erect, mostly unbranched, rarely with single lateral false branching at the heterocytes. Heteropolarity of the filament was reduced (30)35-70(80) $\mu \mathrm{m}$, but still visible. It had scytonematoid character and lost the majority of mucilage layers. Reduced sheaths were still lamellated, both layers being colourless (Figs 1g, h); only old filaments were yellowish. Trichomes were generally constricted at the cross walls, heteropolar, with apical to subapical meristematic zones, with rounded or globular apical cells. Shapes of cells are the same such as in a wild sample, only the size range differs (2.5)5-15 × 7.5-15(16) $\mu \mathrm{m}$. Heterocytes were rare, basal or intercalary, $7.5-10 \times 7.5-10 \mu \mathrm{m}$ in diameter; hormogonia were present often in apical parts of the filaments. Heteropolar development of hormogonia begins from one pole, where cells are intensively divided, the other pole ending cell often becomes a heterocyte. Hormogonia germinated typically within lamellated sheath.

P. alatum from cultures differed significantly in morphological characters (Figs 1-3). They were significantly narrower than that from natural populations (Wilcoxon Signed Ranks Tests, significant value 0.05; Apical zones: $Z=-5,62$, $\mathrm{p}<0.0001$; Heterocyte zones: $Z=-3,16, \mathrm{p}=$ 0.0016; Terminal zones: $Z=-2,09, p=0.0370$ ) The following features were found to be relatively stable: the heteropolarity of trichomes with basal heterocytes, lateral false branching starting at the heterocytes, heteropolar germination; presence of apical or subapical meristematic zones and rounded apical cells.

\section{Discussion}

The taxonomic position of Petalonema and Scytonema species has been based on different morphological features since the beginning of $19^{\text {th }}$ century. The old descriptions (CARMICHAEL in GREVILLE 1823, 1826;BERKELEY 1833;LEMMERMANN 1910; Migula 1915; Geitler 1932) mentioned only the structure type of the trichome sheaths and filament envelopes including the colour. Additional important information (the presence of heterocytes, meristematic zones on trichomes, filament growth and branching) recorded later by Tilden (1910), Kossinskaja (1926), Geitler (1942) and SKuJA $(1929,1964)$ have been found to be crucial. The first more comprehensive set of data on the false branching and sheath structure was recorded by BHARADWAYA (1933). Phycologists interested in these genera, could be separated into groups depending on their interpretation of the morphological data, in particular whether the definition of the main diacritical taxonomic features was validated or shuffled (Table 1). Interestingly, the article published by ZeHNDER (1985) caused taxonomic discussion between phycologists. Based on comparative studies he explained it 

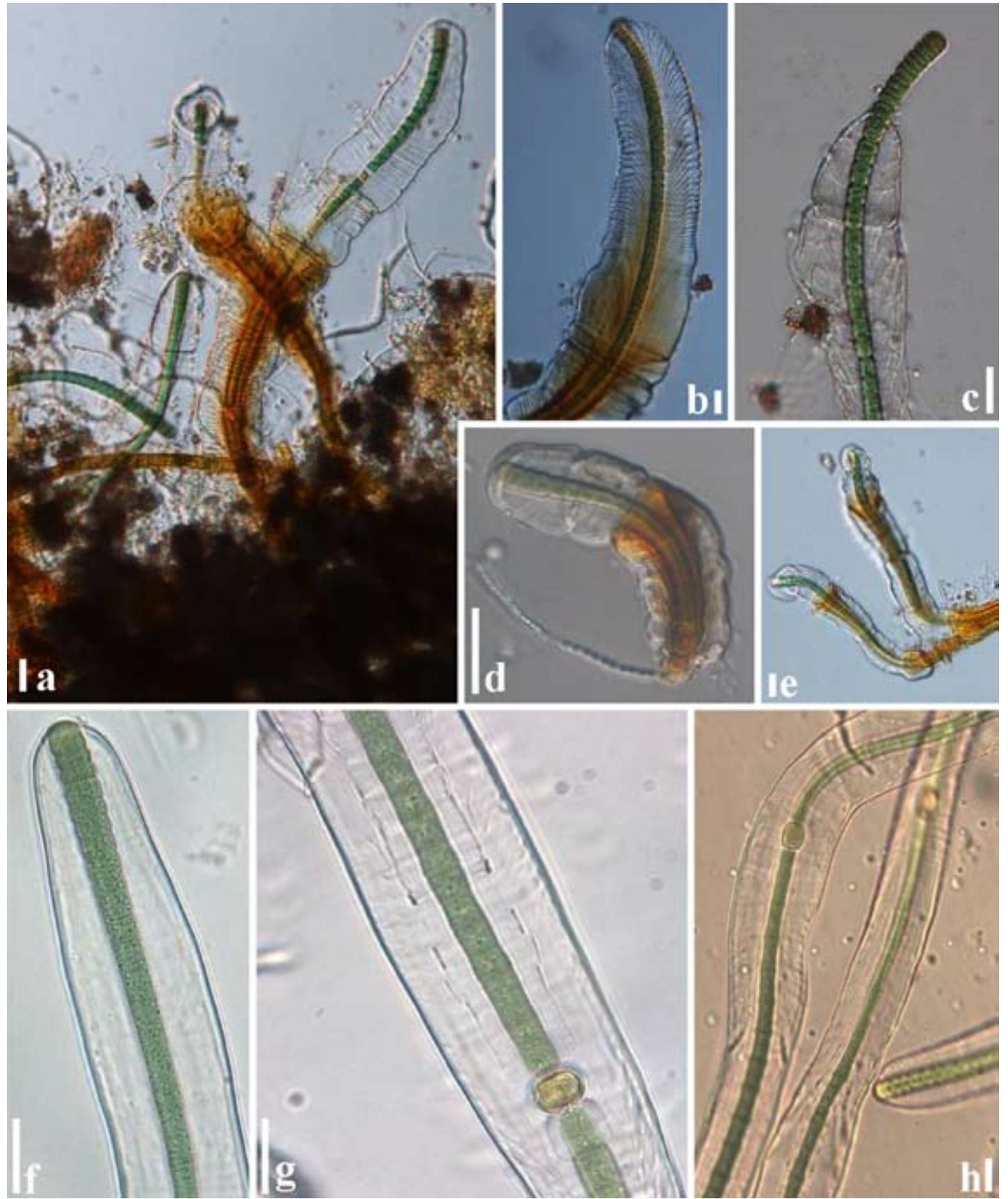

Fig. 1. Petalonema alatum: (a-e) natural sample; (f-h) culture; (a) filament arising from substrate, $(\mathrm{b}, \mathrm{c}, \mathrm{f})$ apices with apical rounded cell, (d) tolypotrichoid fragment of filament; (e) false branching; (g, h) well established sheath stratification. Scale bars $30 \mu \mathrm{m}$.

as follows: "Petalonema alatum and Scytonema myochrous are not, as has been suggested on the basis of observation in situ, ecomorphoses (status) of the same taxon, but two different taxa. Cultured side by side in the laboratory under the same conditions, width and structure of the sheaths are different and thus, these differences are genetically rather than environmentally controlled." In particular, the development of the preferred main diacritical taxonomic features is interesting to observe (Table 1), BERKELEY (1833) stressed the branching, filament lined by lamella, and structure of the envelopes (Petalonema alatum). KomÁreK \& ANAGNostidis (1989) stressed the type of heterocytes, type of branching (asymmetric), wide apex of filament and structured sheath and consequently the genus Petalonema became an independent taxon in the subfamily Tolypotrichoideae of the Microchaetaceae. This relatively complicated history of the taxonomy 

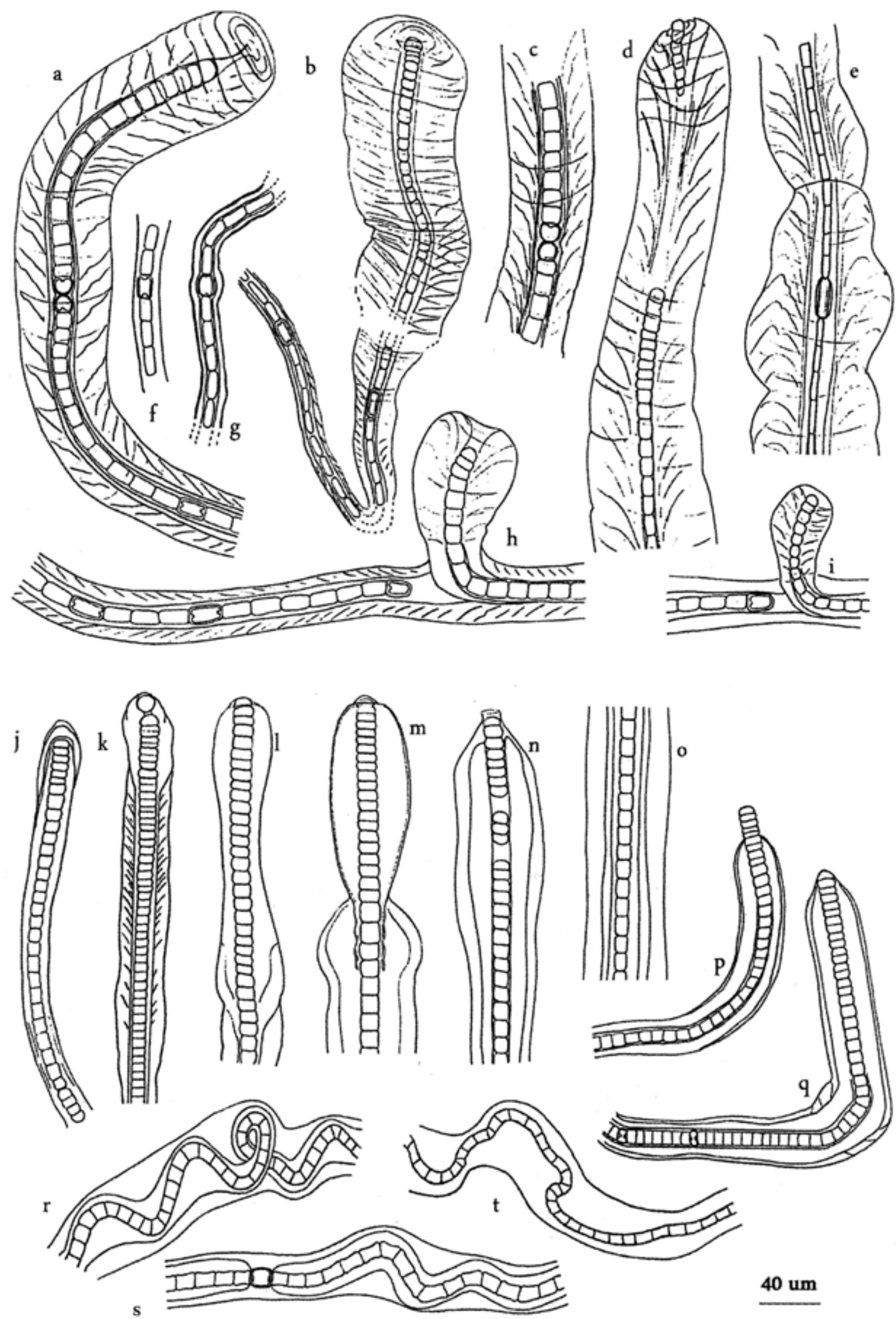

Fig. 2. Iconographs of Petalonema alatum: (a-i) natural sample; $(j-s)$ culture; $(a-c, e-g, j-m, o-q)$ heteropolarity of filaments and sheath stratification; $(\mathrm{d}, \mathrm{n})$ hormogonia formation; $(\mathrm{r}-\mathrm{s})$ trichome spiral-curved in culture. Scale bar $40 \mu \mathrm{m}$ 


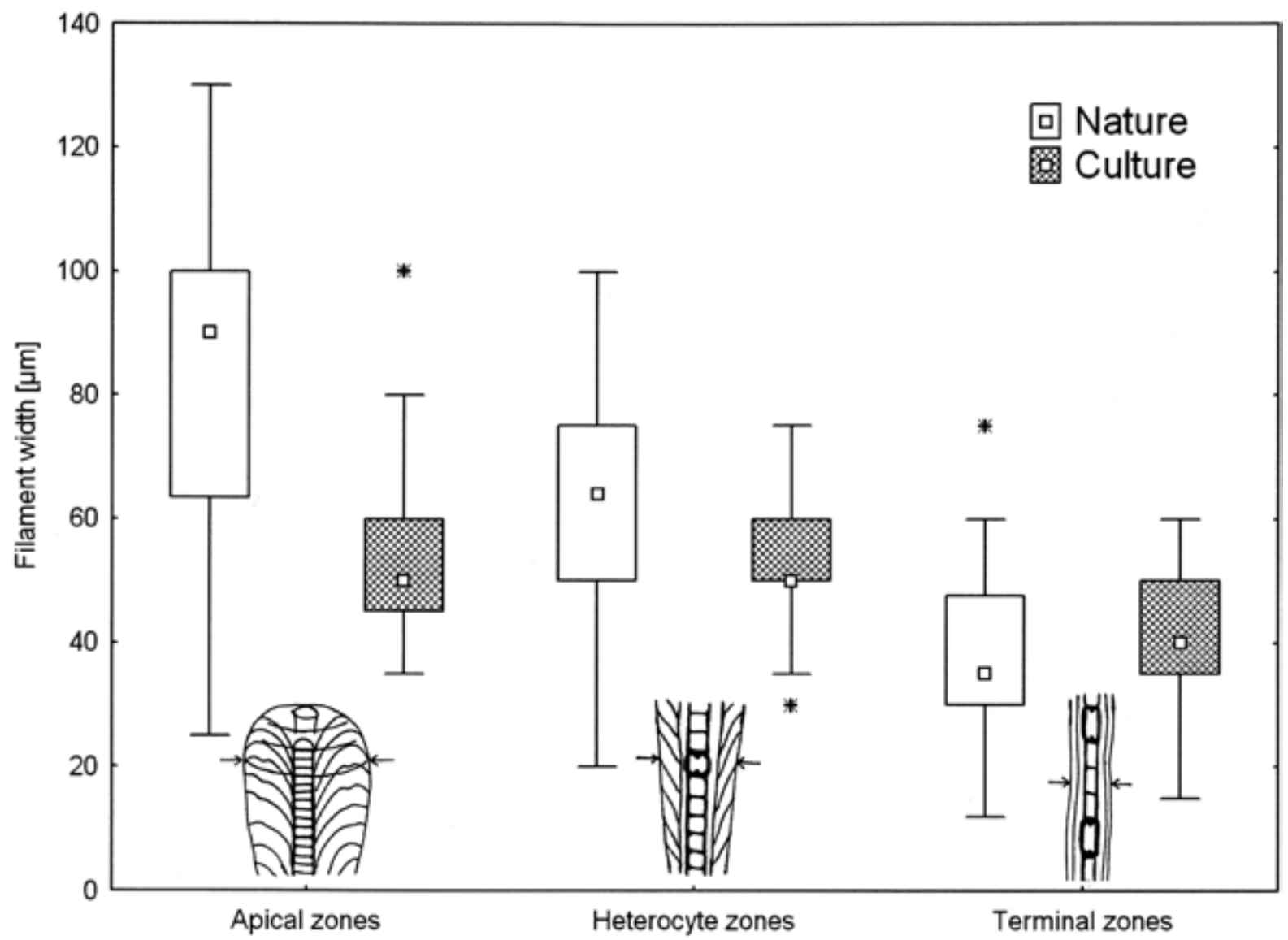

Fig. 3. Comparison of the filament measurements of Petalonema alatum - in nature vs. culture, * outliers, $\square$ median, $\top$ non outlier, box border quantil $25 \%$ and $75 \%$

of the species Petalonema alatum or the genus Petalonema motivated me to do a comparative study based on cultivation and the use of statistical methods to illustrate some suggestions on often discussed diacritical features.

Results presented here confirm that morphological variation of Petalonema alatum under different conditions is broad and the study of similar taxa is still required in order to definitively establish that they do not belong to a life-history stage of P. alatum.

I would like to more definitively say that I agree with KOMÁREK \& ANAGNOSTIDIS 1989 that Petalonema is a valid genus, and that $P$. alatum is more closely affiliated with Tolypothrix in the Microchaetaceae than Scytonema (Figs 1-3). The taxon is defined by the copious sheath with funnel-like lamellations, and while the feature is variable, it still persists in culture (Figs 1-2). The Microchaetaceae and Scytonemataceae are possibly confused, and we certainly need some molecular data to resolve these families. The preliminary phylogenies that exist seem to indicate that the Microchaetaceae are a

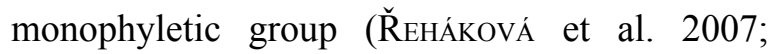
KAŠTOVSKÝ \& JOHANSEN 2008; LuKEŠOVÁ et al. 2009), and Scytonema falls outside of this group (Flechtner et al. 2002). There is currently only one Petalonema that has been sequenced, Petalonema cf. involvens from Antarctica (TATON et al. 2006). Unfortunately, TAтON et al. (2006) did not include many Microchaetaceae in their phylogeny. They placed their Petalonema in the Nostoc clade. Furthermore, the other putative member of Microchaetaceae (an Antarctic Coleodesmium) was close to the Nostoc clade, sister to Nostoc Fin 152, a taxon demonstrated elsewhere to not

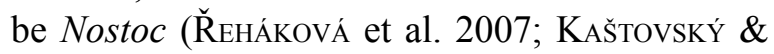
JOHANSEN 2008; LuKEŠOVÁ et al. 2009). The TATON phylogeny does show Scytonema hofmannii distant from Petalonema and Coleodesmium, consistent with FleChTNER et al. (2002).

\section{Acknowledgement}

Financial support for this study was provided by the Funding of Ministry of Education of Czech Republic; project No. MSM0021622416. Author acknowledge 


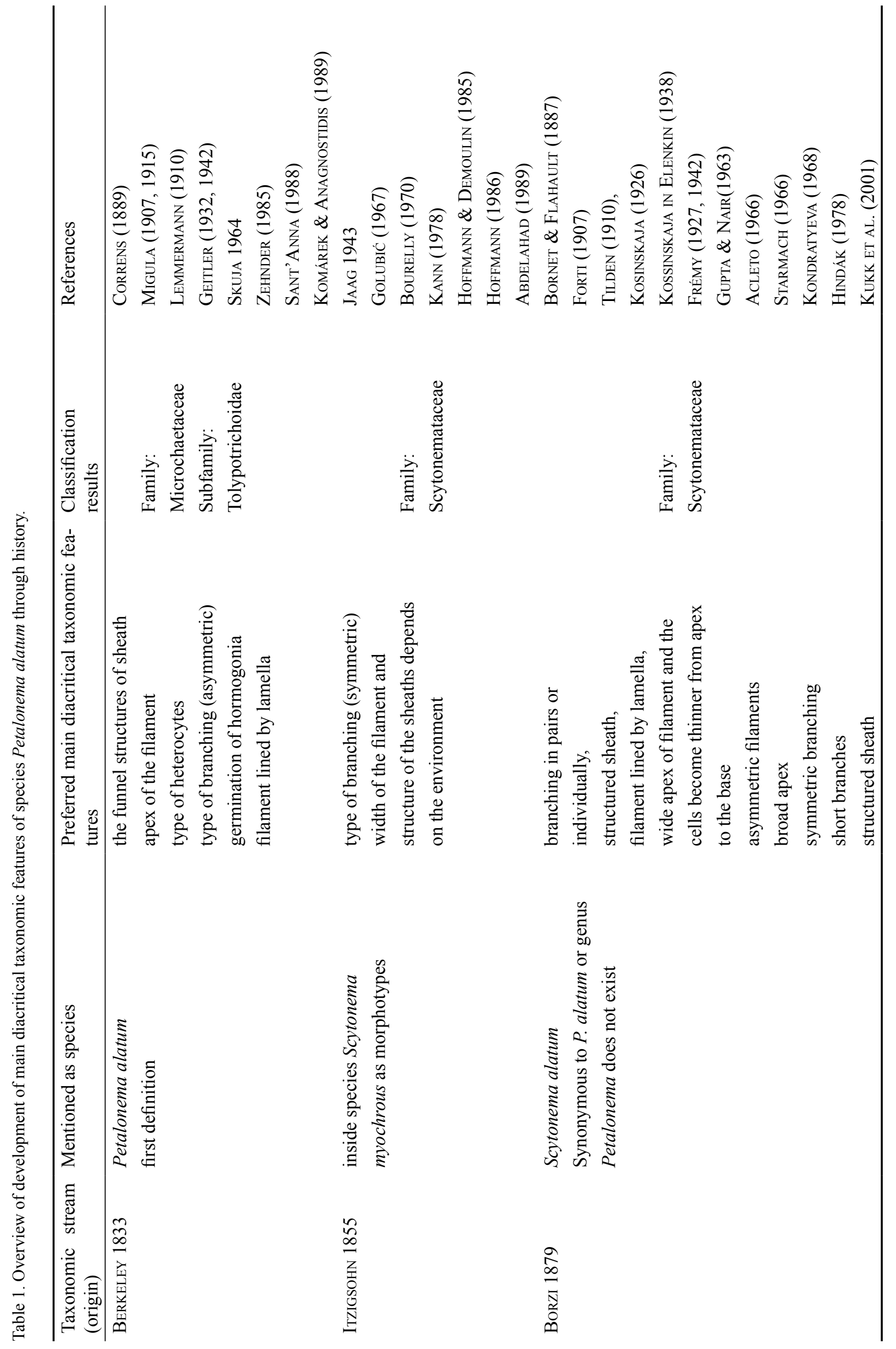




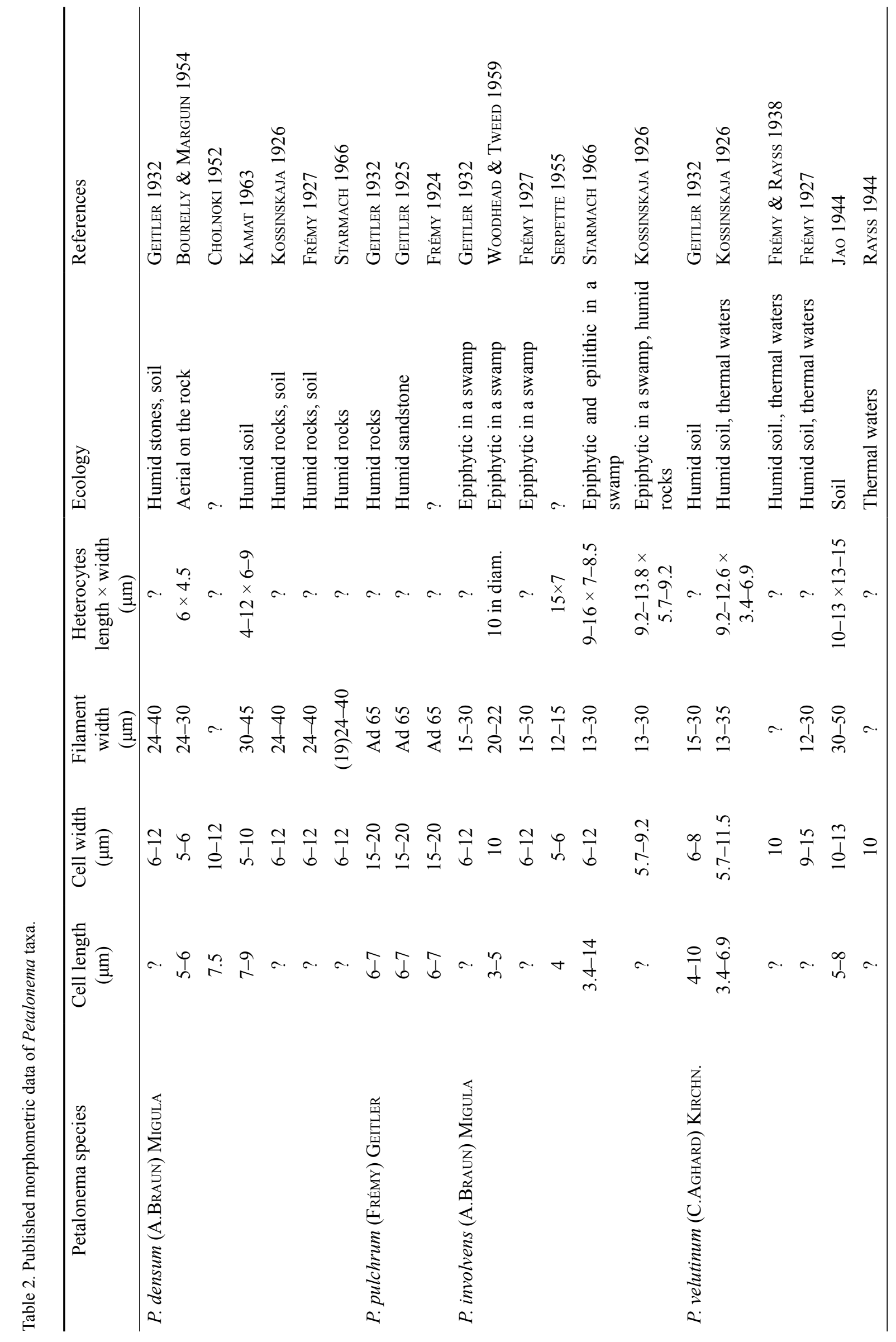




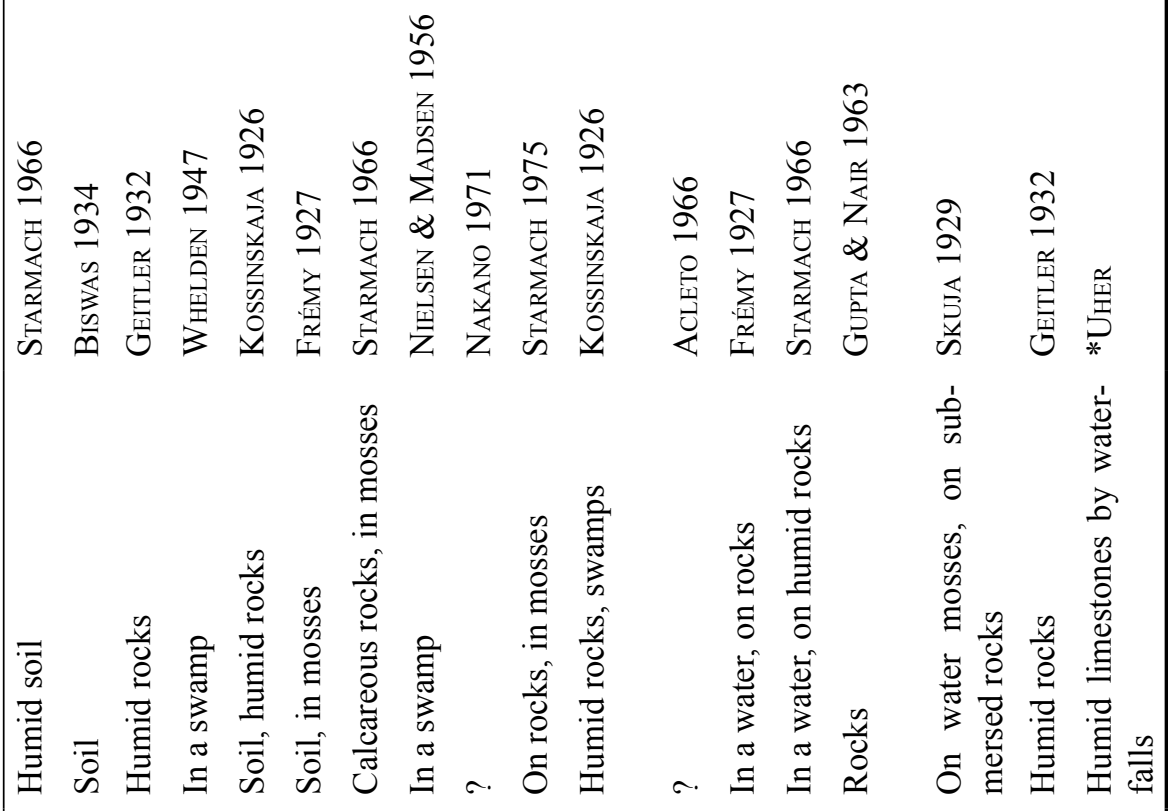

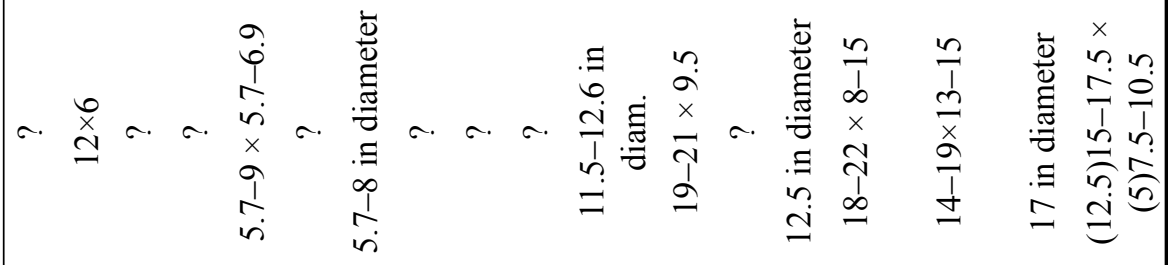

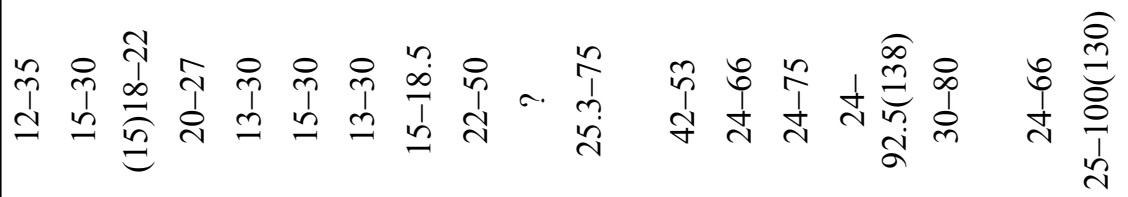

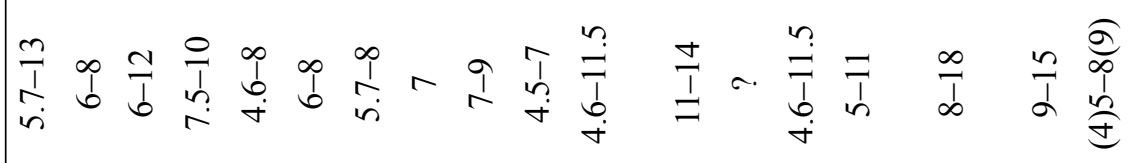

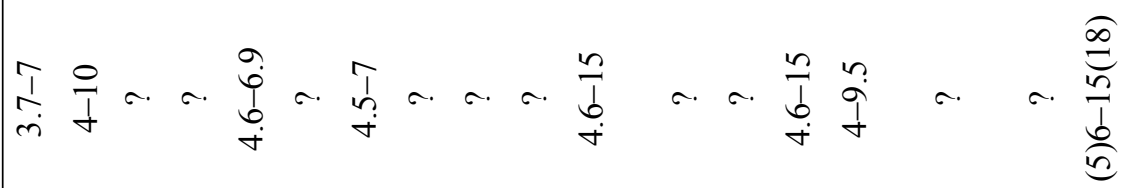

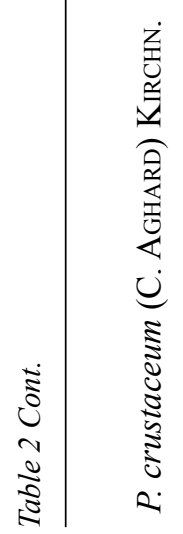


especially reviewer who kindly revised the English style of the manuscript.

\section{References}

Abdelahad, N. (1989): Scytonema myochrous (Dillw.) AG. emend. Jaag (Cyanophyta) dans l'état typique et dans l'état petalonema dans quatre stations épilithiques de la Haute Vallée de l'Aniene (Italie). - Nowa Hedwigia 49: 395403.

Acleto, O.C. (1966): Algae de agua dulce de las cascadas de Barranco. - Rev. Sciencias 68: 21-85.

Berkeley, M.J. (1833): Gleening of British Algae: being an Appendix to the Supplement to English Botany. - 50 pp., C.E. Sowerby, London.

BHARADWAYA, Y. (1933): False branching and sheathstructure in the Myxophyceae, with special reference to the Scytonemataceae. - Arch. Protistenk. 81: 243-283.

BiswAS, K. (1934): Observation on algal collections from Khasia and Jaintia Hills, Assam, India. Hedwigia 74: 1-28.

Bornet, E. \& Flahault, C. (1886): Revision des Nostocacées hétérocystées. - Ann. Sci. Nat. Bot. 5: 51-129.

Bourelly, P. (1970): Les algues d'eau douce: Initiation á la systématique. 3. Les algues bleues et rouges. Les Eugléniens, Peridiniens et Cryptomonadines. - 512 pp., Boubeé et Cie., Paris.

Bourelly, P. \& Manguin, E. (1947): Contribution a la flore algale d'eau douce des Acores. - Societé de Biogéographie, Memoires 8/1946: 447-500.

Borzi, A. (1879): Note alla morfologia e biologia delle Alghe Ficocromacee. - Nuov. Giorn. Bot. Ital. 11: 347-388.

Cholnoki, B.J. (1952): Beiträge zur Kenntnis der Algenflora von Portugiesisch-Ost-Afrika (Mocambique). - I. Bol. Soc. Portug. Cienc. Nat. 4: 89-135.

Correns, C. (1889): Über Dickenwachstum durch Intussusception bei einiger Algenmembranen. Flora 72: 1-298.

ELENKIN, A.A. (1938): Monographia algarum cyanophycearum aquidulcium et terrestrium in finibus URSS inventarum. 1. 2. - 1908 pp., Izd. AN SSSR, Moskva-Leningrad.

Flechtner, V.R., Boyer, S.L., Johansen, J.R. \& DeNoble, M.L. (2002): Spirirestis rafaelensis gen. et sp. nov. (Cyanophyceae), a new cyanobacterial genus from arid soils. - Nova Hedwigia 74:1-24.

ForTI, A. (1907): Sylloge myxophycearum omnium hucusque cognitarum. - In: DE TONi J.B. (ed.): Sylloge algarum omnium, vol. 5. - 761 pp.,
Regii Instituti Veneti Scientiarum, Littearum et Artium Academiaeque Veronensis Sodalis, Padua.

FrÉmY, P. (1924): Contribution à la flore algologique de l'Afrique équatoriale francaise. - Rev. Algol. 1: $28-49$.

FRÉMY, P. (1927): Les Scytonematacées de la France. In: Flore Algologique de France, Cyanopycées, fasc. 1. - 71 pp., Paris et Saint-Lô, Paris.

FRÉMY, P. (1942): Cyanophycées de l'Inde meridionale. - Blumea 2: 21-40.

Frémy, P. \& RAYSS, T. (1938): Algues des sources thermales de Kallirrhoe (Transjorganie). Palestine J. Bot. 1: 27-34.

Geitler L. (1925): Cyanophyceae. - In: Pascher A. (ed.): Süßwasserflora von Mitteleuropa, vol. 12. - 450 pp., Verlag von Gustav Fischer, Jena.

Geitler, L. (1932): Cyanophyceae. - In: Rabenhorst's Kryptogamenflora von Deutschland, Österreich und Schweiz, vol. 14. - 1196 pp., Akad. Verlagsges., Leipzig.

Geitler, L. (1942): Schizophyta (Klasse Schizophyceae). - In: Engler, A. \& Prantl, K. (eds): Natürliche Pflanzenfamilien, vol. 1b. 232 pp., Duncker \& Humbolt, Berlin.

Golubić, S. (1967): Algenvegetation der Felsen. Eine Ökologische Algenstudien im Dinarischen Karstgebiet. - In: Elster, H.J. \& Ohle, W. (eds): Die Binnengewässer, vol. 23. - 183 pp., Schweizerbart'sche Verlagsbuchhandlung, Stuttgart.

GreviLle, R.K. (1823): Scottish cryptogamic flora or coloured figures and desriptions of cryptogamic plants, belonging chiefly to the order Fungi; and intended to serve as a contituation of English Botany, vol. 1. -60 pp., Synopsis generum et specierum cum recensionibus et charscteribus, Edinburgh.

GREVILLE, R.K. (1826): Scottish cryptogamic flora or coloured figures and desriptions of cryptogamic plants, belonging chiefly to the order Fungi; and intended to serve as a contituation of English Botany, vol. 4. - pp. 181-240, Synopsis generum et specierum cum recensionibus et charscteribus, Edinburgh.

Gupta, A. B. \& NAir, G. U. (1963): A contribution to the algal flora of Garhwal. - Agrar. Univ. J. Res. 11: 227-240.

HindÁk, F. (ed.) (1978): Sladkovodné riasy. - 728 pp., SPN, Bratislava.

Hoffmann, L. \& Demoulin, V. (1985): Morphological variability of some species of Scytonemataceae (Cyanophyceae) under different culture conditions. - Bull. Soc. Roy. Bot. Belg. 118: 189-197.

Hoffmann, L. (1986): Cyanophycées aeriennes et subaeriennes du Grand-Duche de Luxembourg. - Bull. Jard. Bot. Nat. Belg. 56: 77-127.

Itzigsohn, H. (1855): Phykologische Studien. - Nova Acta Acad. Leop. 26: 135-166.

JAAG, O. (1943): Scytonema myochrous (Dillw.) Ag., 
Formenkreis und Variabilität einer Blaualge. Boissiera 7: 437-454.

JАO, Сн.-Сн. (1944): Studies on the fresh-water algae of China, 13. New Myxophyceae from Kwangsi. Sinensia 15: 75-90.

KanN, E. (1978): Systematik und Ökologie der Algen Österreichischer Bergbäche. - Arch. Hydrobiol. 53: 405-643.

KAMAT, N.D. (1963): The Alagae of Kolhapur, India. Hydrobiologia 22: 209-305.

Kaštovský, J. \& Johansen, J.R. (2008): Mastigocladus laminosus (Stigonematales, Cyanobacteria): phylogenetic relationship of the strains from thermal springs to the soil-inhabiting genera of the order, and taxonomic implications for the genus. - Phycologia 47: 307-320.

KomÁreK, J. \& Anagnostidis, K. (1989): Modern approach to the classification system of cyanophytes, 4. Nostocales. - Algological Studies 46: 157-226.

Kondratyeva, N.V. (1968): Sino-zeleni vodorosti, Cyanophyta, 2. - In: Viznatshnyk Prisnovnykh Vodorostey Ukrainskoi SSR. - 524 pp., Vidav. Naukova Dumka, Kyiv.

Kossinskaja, E.K. (1926): Monografitsheskij otsherkvidov roda Scytonema sekcii Petalonema. - Bot. Mater. Inst. spor. Rast. Gl. bot. Sada SSSR 4: 57-75.

KukK, E., HÄllfors, G. \& Niemi, A. (2001): Scytonema alatum (Carmichael) BorzÌ (Nostocophyceae, Nostocales) in a lake in Kuusamo, NE Finland. - Algological Studies 140: 47-61.

Lemmermann, E. (1910): Algen 1. - In: Kryptogamenflora d. Mark Brandenburg, vol. 3. - 256 pp., Mark Brandenburg, Leipzig.

Lukešová, A., Johansen, J.R., Martin, M.P. \& Casamatta, D.A. (2009): Aulosira bohemensis sp. nov.: further phylogenetic uncertainty at the base of the Nostocales (Cyanobacteria). Phycologia 48: (in press).

Migula, W. (1907): Algen. 1. Teil. Cyanophyceae, Diatomaceae, Chlorophyceae. - In: Kryptogamen-Flora von Deutschland, DeutschÖsterreich und der Schweiz, vol. 2. - 918 pp., Ramm \& Seemann, Leipzig.

Migula, W. (1915): Die Spaltalgen, Ein Hilfsbuch für Anfänger bei der Bestimmung der am häufigsten vorkommenden Arten. - 73 pp., Franckh'sche Vlg.-handl., Stuttgart.

NaKano, T. (1971): Some aerial amd soil algae from the Ishizuchi mountains. - Hikobia 6: 139-152.

Nielsen, C.S. \& Madsen, G.C. (1956): Florida Scytonemataceae, 2. - Am. Midl. Natural. 56: 116-125.

RAYSS, T. (1944): Materioaux pour la flore algologique de la Palestine, 1. Les Cyanophycées. - Palestine J. Bot. 3: 94-113.

Řeháková, K., Johansen, J.R., Casamatta, D.A.,
Xuesong, L. \& Vincent, J. (2007): Morphological and molecular characterization of selected desert soil cyanobacteria: Three species new to science including Mojavia pulchra gen. et sp. nov. - Phycologia 46: 481502.

SANT'ANNA, C.L. (1988): Scytonemataceae (Cyanophyceae) from the State of São Paulo, southern Brazil. - Nova Hedwigia 46: 519539.

Serpette, M. (1955): Contribution à la l'étude des Cyanophycées de l'Afrique Occidentale. - Bull. IFAN 17: 769-804.

SkujA, H. (1929): Süsswasseralgen von den Wesestnichen Inseln Saareraa und Hiiumaa. Acta Hort. Bot. Univ. Latv. 4: 1-76.

SkujA, H. (1964): Grundzüge der Algenflora und Algenvegetation der Fjeldgegenden um Abisko in schwedische Lappland. - Nova Acta Reg. Soc. Scient. Upsal. 18: 1-465.

Smith, R.L. \& Bold, H.C. (1966): Phycological studies 6. Investigations of the algal genera Eremesphaera and Oocystis. - Univ. Texas Publ. 6612: 1-121.

Starmach, K. (1966): Cyanophyta - sinice, Glaucophyta - glaukofity. - In: StARMACH, K. (ed.): Flora Słodkowodna Polski, vol. 2. 808 pp., Paňstwowe Wydawnictwo Naukowe, Warszawa.

StaRmach, K. (1975): Glony w Wawozie Szopczańskim w Pieninach - Algae in the Szopczański Gorge in the Pieniny Mts. - Fragm. Flor. Geobot. 21: 537-549.

Taton, A., Grubisic, S., Ertz, D., Hodgson, D., Piccardi, R., Biondi, N., Tredici, M., Mainini, M., Losi, D., Marinelli, F. \& Wilmotte, A. (2006): Polyphasic study of Antarctic cyanobacterial strains. - J. Phycol. 42:1257-1270.

Tilden, J. (1910): Minnesota algae 1. - In: The Myxophyceae of North America and Adjacent Regions. - 328 pp., University of Minnesota, Minneapolis.

Whelden, R.M. (1947): Algae. - In: Botany of the Canadian Eastern Arctic, vol. 2. Thallophyta and Bryophyta. - Nat. Mus. Bull. 97: 13-137.

WoodheAd, N. \& Tweed, R.D. (1959): The freshwater algae of Sierra Leone 1. New and unusual algae from the Sula Hills. - Hydrobiologia 12: 181225.

ZEHNDER, A. (1985): Isolation and cultivation of large cyanophytes for taxonomic purposes. Algological Studies 38/39: 281-289.

(C) Czech Phycological Society

Received February 20, 2009

Accepted May 9, 2009 